\title{
CLIMATE ASSESSMENT IN MODERN SUSTAINABLE CATTLE BARNS USING TEMPERATURE-HUMIDITY INDEX
}

\section{Roman Mylostyvyi ${ }^{1}$ \\ Olena Izhboldina ${ }^{2}$}

DOI: https://doi.org/10.30525/978-9934-588-15-0-134

Abstract. The purpose of the study was to study the microclimate in modern uninsulated cattle barns, built with application of the resource-saving technology under the conditions of both natural ventilation and additional normalization of the air environment through the use of powerful axial fans during the heat of summer. The temperature and relative humidity of the cattle barns were investigated directly at the location of the animals in different areas of the premises, recording the indicators continuously for more than a day using remote sensors. Given the high negative correlation between these indices in indoor air $(\mathrm{r}=-0.88, \mathrm{P}<0.05)$, the use of a temperaturehumidity index (THI) to characterize the state of the air environment and to evaluate the combined effect of temperature and humidity on the body of the animals was quite reasonable. The mathematical processing of the results was performed using the software STATISTICA 10 (StatSoft, Inc., USA). Differences between indicators determined by the U-test of MannWhitney ( $U$-test) were considered significant at $\mathrm{P}<0.05$. A high correlation was found between the indoor temperature and humidity conditions and its state in the environment $\left(r=0.95, R^{2}=0.90\right)$. It was found that the state of the air environment in the premises was significantly influenced by their design features. The results of the studies show that the difference in average temperatures inside and outside the premises was up to $4^{\circ} \mathrm{C}$. During the heat, it was cooler at the cattle barns at the account of the roof, which created shady protection from the sun's rays. The relative humidity in the cattle barns was $7-14 \%$ higher than outside, due to the release of

\footnotetext{
${ }^{1}$ Candidate of Veterinary Sciences, Associate Professor, Department of Livestock Processing Technology,

Dnipro State Agrarian and Economic University, Ukraine

${ }^{2}$ Candidate of Agricultural Sciences, Associate Professor,

Department of Livestock Production Technology,

Dnipro State Agrarian and Economic University, Ukraine
} 
moisture by the animals and evaporation from the surrounding structures. Differences in THI indoors and outdoors were up to $2-3$ units $(\mathrm{P}<0.05)$, exceeding the comfortable value for cows $(\mathrm{THI}<68)$ during $18-22$ hours per day. The location of the cattle barn relative to the sides of the world and the degree of its heating with sun rays influenced the value of THI in the premises. The difference between their central and lateral parts reached up to 5 units $(\mathrm{P}<0.05)$. The uneven distribution of THI in cattle barns may affect the milk performance of individual animals, requiring a differentiated approach to additional premise cooling. The constant operation of the axial fans and the open side curtains did not provide the necessary comfort for the animals, which should include the use of additional technical solutions (for example, irrigation) to normalize the microclimate in the cattle barn during the hot summer. The strong reliable relationship between the parameters of the air environment in the cattle barns and the external environment, determined on the basis of multiple simultaneous paired measurements of temperature and relative humidity, as well as their high interdependence, indicates the possibility of applying mathematical modeling methods for the prediction and normalization of microclimate, which will be the subject of our further research.

\section{Introduction}

Current livestock development strategies envisage the introduction of efficient resource-saving technologies. In this sense, particularly in dairy cattle breeding, the construction of new lightweight cattle barns for loose housing is becoming increasingly popular. Premises of lightweight construction (or non-insulated ones) are considered to be the most suitable from the point of view of milk production and cow health $[6$, p. 331; 16]. Compared with the capital premises, they have a lower concentration of harmful gases and more comfortable conditions for animals [4, p. 104; 9]. Due to the use of lightweight enclosures and modern natural ventilation systems, the cattle stall costs less by $24-28 \%$, but the cost of milking and other technological equipment reduces the cost of construction by a third. In addition, the concept of lightweight construction is only economically viable for large dairy farms with more than 300 milk cows [16].

There are also problems in ensuring an optimal microclimate in such premises. Due to the large dimensions, the provided in them ventilation 
systems through the side curtains and light aeration lamps are able to provide the necessary parameters of the air environment only in a narrow range of outside temperatures $[7$, p. $66 ; 17$, p. 1]. Problems with the functionality of non-insulated premises usually occur in winter at temperatures below $-15^{\circ} \mathrm{C}$, when purulent passes begin to freeze [16] and during summer heat, when in the resting place of animals it rises to $+34^{\circ} \mathrm{C}$ when the outside air warms up to $+36^{\circ} \mathrm{C}[1$, p. 37]. The elimination of these problems involves the use of additional (in addition to natural) ventilation systems, which require significant energy consumption and, as a consequence, lead to rise in price of production output.

Among the current trends in the development of microclimate equipment $[3$, p. 212] the automatically controlled processes for maintaining the microclimate, depending on the time of day and day of the week, intermittent heating (cooling) and ventilation of the premises, the algorithm for which are multiple simultaneous studies of the parameters of the ambient air in the premises and outside are especially noteworthy. Being great theoretical importance for further construction of mathematical models and applied one for efficient use of ventilation equipment, such studies require considerable time and effort and are particularly valuable in the context of a particular facility, given the possibility of further implementation of their results in production.

The purpose of the research was to study the microclimate in modern uninsulated barns under conditions of only natural ventilation and with additional normalization of the air environment by the use of powerful axial fans during the heat of summer. The temperature-humidity index (THI), which characterizes the combined effect of air temperature and relative humidity on animals, was selected as an integral indicator of the microclimate condition in the premises, as previous studies [11, p. 103] found a reliable relationship between this indicator and dairy productivity of cows. This manuscript is the continuation of previous reports [12, p. 394; 13, p. 84], made within the framework of the project Biotechnological justification of resource-saving technologies for the production and processing of organic livestock and aquaculture products under the sponsorship of the Ministry of Education and Science of Ukraine (Decree of the Ministry of Education and Science dated 22.12.2018 No.1439) and registration at the Dnipro State Agrarian and Economic University (БM-11/2019). 


\section{Research methodology}

The researches were conducted under the conditions of industrial dairy complexes of the Limited Liability Company MVK Yekaterynoslavskyi and the Private Joint-Stock Company Argo-Soiuz in Dnipropetrovsk region. Indoor and outdoor temperature and humidity were evaluated using an Ambient Weather WS-10 thermohygrometer (Ambient LLC, USA) for more than 30 hours continuously, with sensor readings every 5-20 minutes. The remote sensors $(\mathrm{F} 007 \mathrm{TH})$ were placed at the resting level of the animals (at a height of $50 \mathrm{~cm}$ from the floor) directly between the first and second boxes on the side of the end sections (from the south-east and northwest) and in the central part (between the 1st and the 2nd boxes), just away from the interstall pass with the group drinking pan. Protective covers for the sensors in the form of a solid metal mesh were fixed in the stalls in advance so that the animals could get used to them. The WS-10 thermohygrometer panel was placed outside the premise in shade (Figure 1). Before operation, the sensors and thermohygrometer were adjusted using an Assman aspiration psychrometer [5] in accordance with GOST 6353-52. As well as in our researches, scientists [2, p. 203] measured the temperature and humidity of the air in real time using electronic sensors that were directly above the animal's stalls at a height of $2.5 \mathrm{~m}$. The location of the recorders above the floor at such a distance was motivated by their inaccessibility by animals and maintenance staff (they should not have impede the execution of technological processes on operations). Although the location of the sensors was convenient for data collection, it did not fully reflect the state of the environment at the location of the animals, which directly affects them. We understand that in our case, the presence of animals near the sensors could have influenced their measurements by direct contact (licking, etc.), but the advance (few days before) fastening of covers from the metal mesh without the sensors in the boxes had to prevent "excessive interest" of the cows in the placed equipment.

The condition of the microclimate in the premises and the comfort of the animals were determined by the calculation of the temperature-humidity index (THI) by the equation $[11$, p. 103; 12, p. 394]

$$
T H I=1.8 \times T-(1-B / 100) \times(T-14.3)+32
$$

where $T H I$ is the temperature-humidity index, $T$ is the air temperature, ${ }^{\circ} \mathrm{C}, B$ is the relative humidity, $\%$. 


\section{Roman Mylostyvyi, Olena Izhboldina}
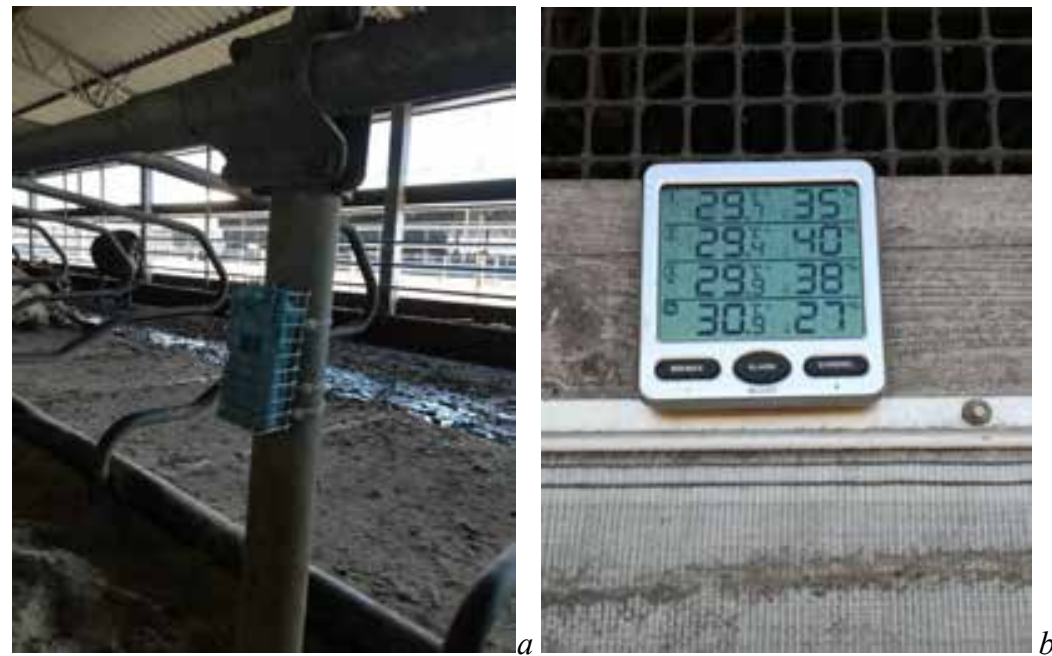

Figure 1. Measurement of temperature and humidity mode in one of the uninsulated barns: one of the sensors (F007TH) is located in the cow resting stall (a), the Ambient Weather WS-10 thermogigrometer is placed outside the barn (b)

The mathematical processing of the obtained results was performed using the software package for statistical analysis STATISTICA 10 (StatSoft, Inc., USA). The differences between the samples, determined by the U-test of Mann-Whitney (U-test), were considered significant at $\mathrm{P}<0.05$.

\section{Climate in an uninsulated barn with natural ventilation}

The LLC MVK Yekaterynoslavskyi (48³4'03.1"N, 3454'47.0"E) is a high-tech innovative dairy complex for keeping Swiss breed. The cows are kept in modern housing for 600 units of milking herd (Figure 2). The premises are placed longitudinally in a direction from northeast to southwest relative to the sides of the world. Each of them has two rows of stalls $(1.2 \times 2.5 \mathrm{~m})$ in four sections (150 units each). Special rubber mattresses create comfort for resting in stalls. The dimensions of the premises in the axes are $240.0 \times 32.4 \mathrm{~m}$. The side walls, $3.0 \mathrm{~m}$ high, have a reinforced concrete base ( $0.4 \mathrm{~m}$ high) with tarpaulin curtains. Additional day and night 
(infrared) illumination provides the necessary light mode indoors. The roof is double-pitch, made of sandwich panels, which allows to maintain the relative constancy of the temperature in the cattle barn, preventing it from overheating or cooling. The ridge height of the premise is $9 \mathrm{~m}$. In the hot season, fans with a large diameter are included to enhance the air exchange. The DeLaval milking parlor collector with Dairy Comp-350 herd monitoring system $(2 \times 20$ parallel type $)$ also has an irrigation system. A mixed diet, balanced according to the nutrition requirements of Nutrient Requirements of Dairy Cattle (2001), is distributed to the feed tables. Balancing of feeding and selection of components of feed mix depending on live weight and performance of cows is carried out in cooperation with the representatives of Cargill (Cargill AT, LLC). Each technological section is equipped with separate feeders with salt, chalk and soda, which allows the animals to eat them freely when needed. In interstall passes there are placed group automated drinking pans with water heating in winter. Manure from the passes is removed by a mobile vehicle (Bobcat S250) when the animals are in the milking parlor.

The side curtains in the pemise under study were constantly open. The ventilation of the premises was natural (powerful fans did not work). During observations, daily temperature fluctuations in ambient air were recorded in the range of +16.6 to $+37.2^{\circ} \mathrm{C}$, and relative humidity -19 to $81 \%$.

It was found that the air temperature in the premise was different from the environment. In particular, it was warmer in the evening, night and morning
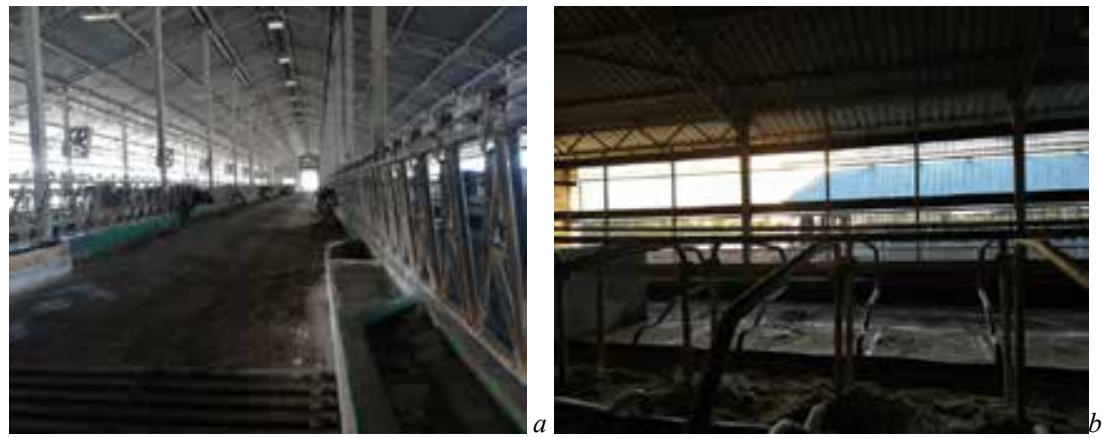

Figure 2. Lightweight premise frame for $\mathbf{6 0 0}$ milk cows: a) inside view of the premise from the side of feed table; b) boxes for cows rest 
(19:00 to 7:00). The difference between maximum indoor and outdoor temperatures was between 0.3 and $3.7^{\circ} \mathrm{C}$. From 9:00 am to 19:00 pm, the premise temperature remained cooler $\left(0.2-4.0^{\circ} \mathrm{C}\right)$ than outside (with rapid warming by the sun).

Differences were also observed in the mean temperature in different parts of the premise. In particular (Table 1), during the day in its central part $\left(25.5^{\circ} \mathrm{C}\right)$ it was cooler by 0.3 and $0.9^{\circ} \mathrm{C}$ than in the south-east and north-west. The maximum temperature difference between the individual sections of the premise was observed at night (at 2:00): between central and southeast - it was $1.1^{\circ} \mathrm{C}$; between central and northwest $-3.6^{\circ} \mathrm{C}$, between southeast and northwest $-2.5^{\circ} \mathrm{C}$. Moreover, in the hot period of day (from 11:00 to 16:00) the temperature difference between the individual sections did not exceed $0.8^{\circ} \mathrm{C}$. In general, taking into account the dynamics of premise temperatures, it was found that for 18 hours straight (from 16:00 to 9:00) it was warmer on the northwest side. The difference between the average temperatures in the frame (at all observation points) and the northwestern side ranged from 0.1 to $2.0^{\circ} \mathrm{C}$. From 10:00 to $15: 00$, the temperature was slightly higher on the southeast side. It exceeded the average one in the frame by $0.2-0.4^{\circ} \mathrm{C}$. In general, temperature fluctuations in the premise occurred in the range of +17.7 to $+34.0^{\circ} \mathrm{C}$ (from the southeast side $-17.7-34.0^{\circ} \mathrm{C}$; in the central part $-18.3-33.2^{\circ} \mathrm{C}$; from the northwest side $-20.2-33.2^{\circ} \mathrm{C}$ ).

Humidity in an uninsulated premise also differed from the outside air. In particular, between midnight and 7:00 am, the relative humidity in the livestock building was lower. The difference between its average indoor and outdoor values ranged from 0.7 to $6.8 \%$. In the morning (after 8:00) and until night (24:00), the humidity in the premise was higher by $0.2-11.4 \%$. It was found (Table 2) that during the day the average value of relative humidity (54.2\%) from the northwestern side was higher by 1.1 and $2.4 \%$, respectively, than in the central and southeastern parts. The maximum difference between the individual sections of the premise according to this parameter of the air environment was observed in the evening (from 19:00 to 22:00): between central and southeast $-10.6 \%$; between central and northwest $-6.8 \%$, between southeast and northwest $-11.8^{\circ} \mathrm{C}$. During the heat period from 11:00 to 16:00 the maximum difference in humidity between these parts of the livestock building was only $5.4 ; 6.7$ and $7.8 \%$, respectively. Given the dynamics of relative humidity, it can be affirmed 
Table 1

Dynamics of air temperature $\left({ }^{\circ} \mathrm{C}\right)$ in an uninsulated cow barn during

24 hours $(\mathrm{n}=162, \bar{X} \pm S E)$

\begin{tabular}{|c|c|c|c|c|}
\hline & Outside & \multicolumn{3}{|c|}{ Premise } \\
\hline Day time & in shade & southeast side1 & cetral part 2 & northwest side3 \\
\hline $1: 00$ & $18.2 \pm 0.08$ & $20.6 \pm 0.13 *(2,3)$ & $19.6 \pm 0.16 *(1,3)$ & $21.9 \pm 0.32 *(1,2)$ \\
\hline $2: 00$ & $17.5 \pm 0.13$ & $19.5 \pm 0.19 *(2,3)$ & $18.4 \pm 0.05 *(1,3)$ & $22.5 \pm 0.36 *(1,2)$ \\
\hline $3: 00$ & $16.7 \pm 0.11$ & $18.7 \pm 0.04$ & $18.6 \pm 0.07$ & $20.6 \pm 0.28$ \\
\hline $4: 00$ & $16.7 \pm 0.14$ & $19.4 \pm 0.71$ & $20.2 \pm 0.92$ & $20.8 \pm 0.21$ \\
\hline $5: 00$ & $17.7 \pm 0.22$ & $20.4 \pm 0.15 *(2,3)$ & $21.3 \pm 0.17 *(1)$ & $21.3 \pm 0.09 *(1)$ \\
\hline $6: 00$ & $19.9 \pm 0.32$ & $20.7 \pm 0.08 *$ & $21.3 \pm 0.06^{*}$ & $21.2 \pm 0.08 *$ \\
\hline $7: 00$ & $22.9 \pm 0.62$ & $22.9 \pm 0.47$ & $22.5 \pm 0.39$ & $23.5 \pm 0.43$ \\
\hline $8: 00$ & $25.9 \pm 0.27$ & $26.0 \pm 0.39$ & $25.2 \pm 0.36(3)$ & $26.2 \pm 0.29(2)$ \\
\hline 9:00 & $27.6 \pm 0.25$ & $27.8 \pm 0.26(2)$ & $26.9 \pm 0.28 *(1)$ & $27.9 \pm 0.35$ \\
\hline $10: 00$ & $29.2 \pm 0.46$ & $29.1 \pm 0.41$ & $28.7 \pm 0.45$ & $28.7 \pm 0.53$ \\
\hline $11: 00$ & $31.3 \pm 0.52$ & $30.9 \pm 0.52$ & $30.5 \pm 0.53$ & $30.1 \pm 0.53$ \\
\hline $12: 00$ & $33.1 \pm 0.60$ & $31.7 \pm 0.56^{*}$ & $31.3 \pm 0.56^{*}$ & $31.5 \pm 0.45^{*}$ \\
\hline $13: 00$ & $33.8 \pm 0.81$ & $31.8 \pm 0.69$ & $31.4 \pm 0.67 *$ & $31.5 \pm 0.59 *$ \\
\hline $14: 00$ & $34.3 \pm 0.47$ & $31.3 \pm 0.46^{*}$ & $31.0 \pm 0.41 *$ & $31.1 \pm 0.38^{*}$ \\
\hline $15: 00$ & $34.6 \pm 0.62$ & $32.4 \pm 0.70$ & $31.7 \pm 0.66^{*}$ & $32.7 \pm 0.56^{*}$ \\
\hline $16: 00$ & $32.6 \pm 0.23$ & $30.9 \pm 0.29 *(2,3)$ & $30.5 \pm 0.24 *(1,3)$ & $31.3 \pm 0.19 *(1,2)$ \\
\hline $17: 00$ & $31.8 \pm 0.18$ & $30.5 \pm 0.12$ & $30.3 \pm 0.04$ & $31.1 \pm 0.11$ \\
\hline $18: 00$ & $34.3 \pm 1.78$ & $30.1 \pm 0.15$ & $30.2 \pm 0.11$ & $30.7 \pm 0.22$ \\
\hline $19: 00$ & $30.1 \pm 0.46$ & $29.7 \pm 0.18$ & $30.3 \pm 0.19$ & $31.4 \pm 0.41$ \\
\hline $20: 00$ & $27.4 \pm 0.51$ & $27.9 \pm 0.46(3)$ & $28.1 \pm 0.27(3)$ & $29.6 \pm 0.08 *(1,2)$ \\
\hline $21: 00$ & $24.5 \pm 0.32$ & $25.7 \pm 0.18 *(3)$ & $26.2 \pm 0.26^{*}(3)$ & $27.4 \pm 0.42 *(1,2)$ \\
\hline $22: 00$ & $22.3 \pm 0.23$ & $24.3 \pm 0.21 *$ & $24.3 \pm 0.22 *$ & $24.6 \pm 0.31 *$ \\
\hline $23: 00$ & $20.4 \pm 0.28$ & $22.0 \pm 0.26 *(3)$ & $21.3 \pm 0.48 *(3)$ & $22.9 \pm 0.27 *(1,2)$ \\
\hline $24: 00$ & $19.1 \pm 0.12$ & $21.3 \pm 0.07 *(2,3)$ & $20.0 \pm 0.19 *(1,3)$ & $22.3 \pm 0.19 *(1,2)$ \\
\hline
\end{tabular}

Note: * - significant difference $(\mathrm{P}<0.05)$ between indices outside and indoors; (1), (2), (3) is a significant difference between individual parts according to the U-test of MannWhitney (U-test).

that during 13 hours of the day (from 8 am to $9 \mathrm{pm}$ ), the southeast side of the premise was drier than other areas. The difference between the average relative humidity in the building and separately in the southeastern part increased to $6.4 \%$. In general, its values in the air of the premise ranged from 27 to $76 \%$ (outside, the variation ranged from 19 to $81 \%$ ). 
Table 2

Dynamics of the air relative humidity in an uninsulated cow barn during 24 hours $(\mathrm{n}=162, \bar{X} \pm S E)$

\begin{tabular}{|c|c|c|c|c|}
\hline & Outside & \multicolumn{3}{|c|}{ Premise } \\
\hline Day time & in shade & southeast side1 & cetral part2 & northwest side3 \\
\hline $1: 00$ & $73.1 \pm 0.50$ & $71.1 \pm 0.80(2,3)$ & $68.9 \pm 0.37 *(1)$ & $68.3 \pm 0.47 *(1)$ \\
\hline $2: 00$ & $74.9 \pm 0.15$ & $70.9 \pm 0.28^{*}(3)$ & $71.1 \pm 0.55^{*}$ & $66.5 \pm 1.08^{*}(1)$ \\
\hline $3: 00$ & $77.7 \pm 0.41$ & $70.1 \pm 0.03$ & $72.7 \pm 0.41$ & $70.6 \pm 1.87$ \\
\hline $4: 00$ & $80.0 \pm 1.41$ & $74.5 \pm 2.12^{*}$ & $74.5 \pm 0.71^{*}$ & $74.5 \pm 0.71^{*}$ \\
\hline $5: 00$ & $78.8 \pm 0.34$ & $74.2 \pm 0.66$ & $75.2 \pm 0.44$ & $73.8 \pm 0.52$ \\
\hline $6: 00$ & $73.6 \pm 1.13$ & $70.3 \pm 0.51^{*}$ & $69.4 \pm 0.46^{*}(3)$ & $71.6 \pm 0.32(2)$ \\
\hline $7: 00$ & $65.3 \pm 2.09$ & $64.3 \pm 1.83$ & $65.8 \pm 1.25$ & $63.8 \pm 2.52$ \\
\hline $8: 00$ & $51.5 \pm 0.97$ & $52.3 \pm 0.92$ & $54.7 \pm 1.32$ & $54.7 \pm 1.15$ \\
\hline $9: 00$ & $44.0 \pm 0.47$ & $47.4 \pm 0.52^{*}$ & $48.3 \pm 0.65^{*}$ & $48.4 \pm 0.78^{*}$ \\
\hline $10: 00$ & $39.6 \pm 0.78$ & $43.9 \pm 1.04 *$ & $44.1 \pm 1.13 *$ & $43.7 \pm 0.56^{*}$ \\
\hline $11: 00$ & $35.2 \pm 0.75$ & $37.7 \pm 0.82(2,3)$ & $43.1 \pm 2.38^{*}(1,3)$ & $43.4 \pm 0.52^{*}(1,2)$ \\
\hline $12: 00$ & $29.4 \pm 0.64$ & $34.3 \pm 0.56^{*}(3)$ & $35.4 \pm 1.74^{*}(3)$ & $41.3 \pm 0.63 *(1,2)$ \\
\hline $13: 00$ & $25.9 \pm 1.01$ & $32.7 \pm 1.37 *$ & $35.6 \pm 2.13^{*}$ & $37.1 \pm 1.37^{*}$ \\
\hline $14: 00$ & $23.8 \pm 0.82$ & $31.6 \pm 0.74^{*}(2,3)$ & $35.8 \pm 1.53^{*}(1)$ & $38.2 \pm 0.74 *(1)$ \\
\hline $15: 00$ & $23.1 \pm 1.23$ & $30.9 \pm 1.72(3)$ & $32.0 \pm 2.30^{*}(3)$ & $38.7 \pm 1.05^{*}(1 ; 2)$ \\
\hline $16: 00$ & $27.7 \pm 0.91$ & $37.5 \pm 1.81^{*}$ & $39.4 \pm 1.21^{*}(3)$ & $37.9 \pm 0.36^{*}(2)$ \\
\hline $17: 00$ & $30.7 \pm 0.41$ & $36.7 \pm 0.41$ & $40.7 \pm 0.41$ & $39.3 \pm 1.08$ \\
\hline $18: 00$ & $34.3 \pm 1.78$ & $38.7 \pm 1.08$ & $42.5 \pm 0.71$ & $44.7 \pm 3.08$ \\
\hline $19: 00$ & $39.0 \pm 1.41$ & $39.7 \pm 0.41$ & $50.3 \pm 2.16$ & $48.3 \pm 0.41$ \\
\hline $20: 00$ & $46.6 \pm 0.84$ & $43.2 \pm 0.55^{*}(2,3)$ & $48.2 \pm 0.42(1,3)$ & $55.3 \pm 2.74 *(1,2)$ \\
\hline $21: 00$ & $48.8 \pm 0.47$ & $49.3 \pm 1.12(2,3)$ & $51.8 \pm 0.65^{*}(1,3)$ & $56.4 \pm 0.84^{*}(1,2)$ \\
\hline $22: 00$ & $52.1 \pm 0.44$ & $58.1 \pm 1.50^{*}$ & $55.3 \pm 0.21^{*}$ & $55.6 \pm 0.57^{*}$ \\
\hline $23: 00$ & $57.7 \pm 1.02$ & $63.9 \pm 1.78^{*}(2)$ & $56.9 \pm 0.57(1,3)$ & $65.6 \pm 2.05^{*}(2)$ \\
\hline $24: 00$ & $67.2 \pm 1.59$ & $70.3 \pm 0.23(2,3)$ & $65.2 \pm 1.95(1)$ & $66.7 \pm 0.88(1)$ \\
\hline
\end{tabular}

Note: see Table 1.

During the day, the THI fluctuations outside the premises occurred in the range of 61.4 to 80.6. In the uninsulated barn, this figure ranged from 63.7 to 82.8 . The difference between the average value of THI outside and inside the premise was 1.5 units. (Table 3). The maximum difference in THI magnitude was observed at night and especially in the morning. This figure was 3.2-5.1 units higher than outside. However, during the heat (from 12:00 to 16:00), the differences in indoor and outdoor air values were only $0.1-1.5$ units, with THI values being 
higher outside the premise. In the same building, the maximum difference in this indicator between separate parts of the premise during the day was: at night (0:00-2:00) - 5.1; in the morning (3:00-11:00) - 1.7; at lunch (12:00-15:00) 1.6 and in the evening (16:00-23:00) - 3.2. Although the average value of the index in the southeast, central and northwestern parts did not differ significantly and was respectively $72.5 \pm 0.96 ; 72.4 \pm 1.03$ and $73.9 \pm 0.90$. That is, on the northwest side, the THI is 1.4-1.5 units higher than in other parts of the premise.

Table 3

\section{Dinamics of the temperature-humidity index in an uninsulated cow barn during 24 hours $(\mathrm{n}=162, \bar{X} \pm S E)$}

\begin{tabular}{|c|c|c|c|c|}
\hline & Outside & \multicolumn{3}{|c|}{ Premise } \\
\hline Day time & in shade & southeast side1 & cetral part2 & northwest side3 \\
\hline $1: 00$ & $63.7 \pm 0.11$ & $67.3 \pm 0.17 *(2,3)$ & $65.6 \pm 0.25 *(1,3)$ & $68.9 \pm 0.49 *(1,2)$ \\
\hline $2: 00$ & $62.7 \pm 0.22$ & $65.6 \pm 0.28^{*}(2,3)$ & $63.9 \pm 0.07 *(1,3)$ & $69.3 \pm 0.48^{*}(1,2)$ \\
\hline $3: 00$ & $61.6 \pm 0.15$ & $64.5 \pm 0.04(2,3)$ & $64.3 \pm 0.11(1)$ & $67.2 \pm 0.36(1)$ \\
\hline $4: 00$ & $61.6 \pm 0.21$ & $65.7 \pm 1.25$ & $66.8 \pm 1.48$ & $67.7 \pm 0.28$ \\
\hline $5: 00$ & $63.2 \pm 0.35$ & $67.1 \pm 0.23 *(2,3)$ & $68.8 \pm 0.27 *(1)$ & $68.6 \pm 0.18^{*}(1)$ \\
\hline $6: 00$ & $66.3 \pm 0.44$ & $67.4 \pm 0.09^{*}(2,3)$ & $68.2 \pm 0.13 *(1)$ & $68.2 \pm 0.12 *(1)$ \\
\hline $7: 00$ & $70.2 \pm 0.75$ & $70.1 \pm 0.52$ & $69.7 \pm 0.47$ & $70.9 \pm 0.59$ \\
\hline $8: 00$ & $73.0 \pm 0.39$ & $73.2 \pm 0.42$ & $72.4 \pm 0.34(3)$ & $73.8 \pm 0.35(2)$ \\
\hline $9: 00$ & $74.2 \pm 0.28$ & $75.0 \pm 0.36(2)$ & $73.8 \pm 0.30(1,3)$ & $75.2 \pm 0.42(2)$ \\
\hline $10: 00$ & $75.6 \pm 0.51$ & $76.2 \pm 0.43$ & $75.5 \pm 0.44$ & $75.6 \pm 0.64$ \\
\hline $11: 00$ & $77.3 \pm 0.55$ & $77.2 \pm 0.52$ & $77.7 \pm 0.83$ & $77.1 \pm 0.62$ \\
\hline $12: 00$ & $78.3 \pm 0.64$ & $77.6 \pm 0.59 *(3)$ & $77.3 \pm 0.39(3)$ & $78.6 \pm 0.48(1,2)$ \\
\hline $13: 00$ & $78.3 \pm 0.73$ & $77.4 \pm 0.73$ & $77.4 \pm 0.55$ & $77.9 \pm 0.67$ \\
\hline $14: 00$ & $78.5 \pm 0.35$ & $76.6 \pm 0.39 *(3)$ & $77.2 \pm 0.23 *$ & $77.5 \pm 0.37 *(1)$ \\
\hline $15: 00$ & $78.7 \pm 0.41$ & $77.8 \pm 0.47 *$ & $77.2 \pm 0.36 *$ & $78.8 \pm 0.68$ \\
\hline $16: 00$ & $77.5 \pm 0.19$ & $77.2 \pm 0.24$ & $77.1 \pm 0.12(3)$ & $77.8 \pm 0.26(2)$ \\
\hline $17: 00$ & $77.1 \pm 0.23$ & $76.7 \pm 0.08$ & $77.1 \pm 0.11$ & $77.8 \pm 0.29$ \\
\hline $18: 00$ & $77.0 \pm 0.07$ & $76.5 \pm 0.11$ & $77.2 \pm 0.04$ & $78.1 \pm 0.32$ \\
\hline $19: 00$ & $76.5 \pm 0.32$ & $76.1 \pm 0.15$ & $78.2 \pm 0.58$ & $79.6 \pm 0.45$ \\
\hline $20: 00$ & $74.3 \pm 0.54$ & $74.5 \pm 0.51(3)$ & $75.4 \pm 0.35(3)$ & $78.4 \pm 0.41 *(1,2)$ \\
\hline $21: 00$ & $70.9 \pm 0.38$ & $72.5 \pm 0.13 *(3)$ & $73.1 \pm 0.27 *(3)$ & $75.7 \pm 0.67 *(1,2)$ \\
\hline $22: 00$ & $68.3 \pm 0.28$ & $71.6 \pm 0.23 *(2)$ & $70.8 \pm 0.33 *(1)$ & $71.7 \pm 0.42 *$ \\
\hline $23: 00$ & $66.2 \pm 0.33$ & $68.8 \pm 0.25 *(3)$ & $67.3 \pm 0.62(3)$ & $70.3 \pm 0.48 *(1,2)$ \\
\hline $24: 00$ & $64.8 \pm 0.11$ & $68.3 \pm 0.12 *(2,3)$ & $66.1 \pm 0.39 *(1,3)$ & $69.5 \pm 0.35 *(1,2)$ \\
\hline
\end{tabular}

Note: see Table 1. 
Environmental parameters such as temperature and relative humidity are closely related. The correlation coefficient between them was negative ( $r=$ -0.939; $\mathrm{P}<0.001)$ with high interdependence $\left(R^{2}=0.88\right)$. In the indoor air, this relationship has increased (to $r=-0.972 ; R^{2}=0.94$ ), and it is therefore quite evident that the use of THI for the joint assessment of their effect on the animal's condition is quite convenient. Overall, the indoor climate was largely related to the state of the environment $\left(r=0.95 ; R^{2}=0.90\right)$. However, the highest correlation between the environment THI and the value of this indicator indoors was observed on the southeast side $\left(r=0.98 ; R^{2}=0.96\right)$.

Based on our data, during the 24 hours, cows located in the central and southeastern parts of the premise could have felt discomfort for 18 hours, and in the northwest for 22 hours. At the same time, indicators of temperature and humidity, which corresponded to the stressful condition of animals (THI $>68$ ) outside the premise in the shade lasted only 16 hours. The differences found in the uneven distribution of temperature and humidity in the premise are attributed to its design features and location relative to the sides of the world. The obtained data indicate the need for additional use of active ventilation not only during the hot period, but also other hours of the day, depending on the area of the premise.

\section{Microclimate in an uninsulated barn with normalization of air environment}

The dairy complex of Private Joint-Stock Company Agro-Soiuz $\left(48^{\circ} 28^{\prime} 44^{\prime \prime} \mathrm{N}, 35^{\circ} 36^{\prime} 46^{\prime \prime} \mathrm{E}\right)$ has breeding status for breeding Holstein breed. Cows are kept free in lightweight buildings built with resource-saving technology A microclimate study was conducted in a hangar type premise with medium-lactation animals (91 to 210 days). Their number in the sections, designed for 150 cows, was $127-143$ units. The average daily milk yield for this technology group was $24-26 \mathrm{~kg}$. This barn is located from north to south relative to the sides of the world, has tent covering, fitted with plastic side curtains, its dimensions in the axes are $124 \times 34.5 \mathrm{~m}$, ridge height $-8.25 \mathrm{~m}$. The total area of the premise per cow is $4.3 \mathrm{~m}^{2}$ (including the stall $\left.-2.24 \mathrm{~m}^{2}\right)$. It is equipped with a feed table and group automated drinking pans (Figure 3 ).

Studies of the air temperature and the relative humidity in the premise were conducted in the range of outdoor temperatures from $+19.2^{\circ} \mathrm{C}$ to 


\section{Chapter «Agricultural sciences»}
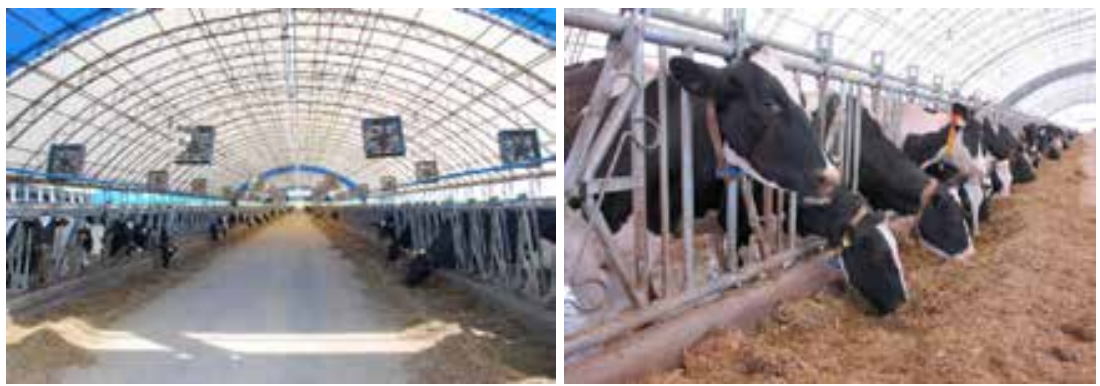

Figure 3. Non-insulated barn of hangar type with tent coating

$+36.9^{\circ} \mathrm{C}$. It was found that the microclimate in the barn was dependent on the state of the environment. The correlation between indoor and outdoor air temperatures was $\mathrm{r}=+0.962\left(R^{2}=0.93\right)$, with the mean temperature inside and outside of the cattle barn not significantly different (Figure 4). At an outside temperature of $+20-23^{\circ} \mathrm{C}$ (at night and early in the morning) the temperature difference inside and outside the premise did not exceed $0.3^{\circ} \mathrm{C}$. In the morning and at noon, when the outside temperature warmed up to $+32^{\circ} \mathrm{C}$, the cattle barn was warmer by $1.5-2.0^{\circ} \mathrm{C}$. We associate this with the ability of the premise to preserve the heat produced by the animals.

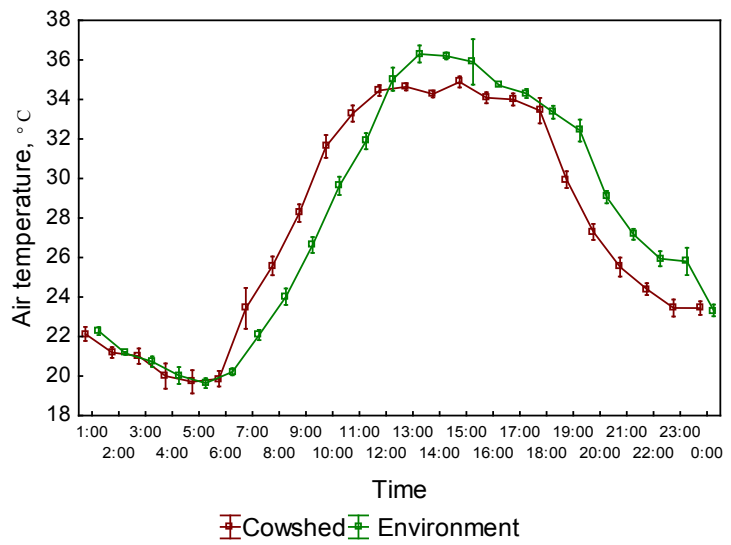

Figure 4. Dynamics of average temperatures outside (green line) and inside (dark-red line) of an uninsulated barn, $n=402$ 
During the heat, when the ambient air heated above $+35^{\circ} \mathrm{C}$, the tent of the cattle barn served as a shadow protection for the animals. The premise was cooler. The average temperature difference was up to $1.9^{\circ} \mathrm{C}$. In the evening, when the outside temperature drops below $+32^{\circ} \mathrm{C}$ and till midnight, the uninsulated barn cooled by $1.5-2.5^{\circ} \mathrm{C}$, which is due to the faster cooling of the premise in which the axial fans are operated.

The temperature in different parts of the premise, which has a northsouth location relative to the sides of the world, differed significantly (Table 4). From 7:00 am to noon, the southwestern part of the premise was warmer by $0.5-3.0^{\circ} \mathrm{C}$ than the southeastern part of the premise, which was probably due to the warming of the barn by the rays of the rising sun.

At noon and 6:00 pm the northwest side was warming more strongly. The temperature here was higher by $0.3-1.2^{\circ} \mathrm{C}$. The temperature difference in the center and ends of the barn during the day ranged from 0.1 to $3.7^{\circ} \mathrm{C}$.

The relative humidity of the barn depended on the state of the environment (Figure 5). The correlation between the relative humidity inside and outside the premise was $\mathrm{r}=+0.954(\mathrm{R} 2=0.91)$. Its average values in the cattle barn were the highest (48.2-55.9\%) at night and early in the morning before sunrise. The difference between the relative humidity indoors and outdoors at this time was low (0.7-3.4\%). At noon and up to 16:00 with maximum warming of atmospheric air, its humidity decreased (up to $13.5 \%$ ). However,

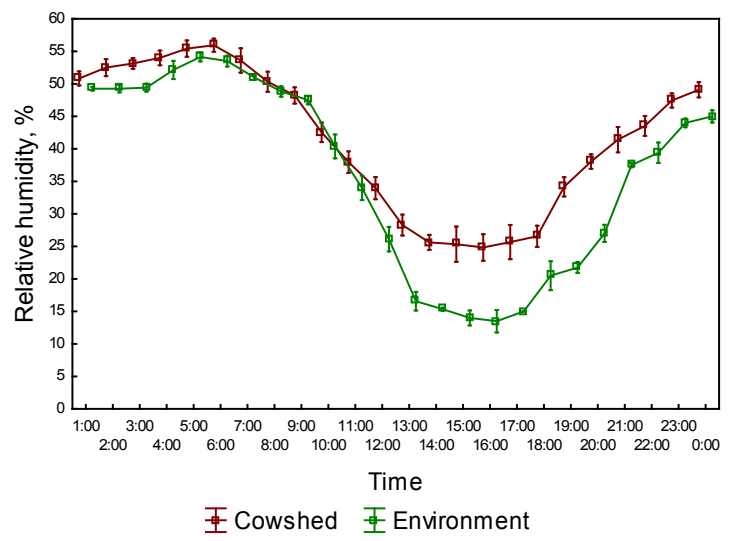

Figure 5. Dynamics of average relative humidity outside (green line) and inside (dark-red line) of uninsulated barn, $n=402$ 
Table 4 Dynamics of air temperature $\left({ }^{\circ} \mathrm{C}\right)$ in an uninsulated cow barn during 24 hours $(\mathrm{n}=134, \bar{X} \pm S E)$

\begin{tabular}{|c|c|c|c|c|}
\hline & Outside & \multicolumn{3}{|c|}{ Premise } \\
\hline Day time & in shade & southeast side1 & cetral part 2 & northwest side3 \\
\hline $1: 00$ & $22.3 \pm 0.20$ & $22.1 \pm 0.31$ & $22.6 \pm 0.23$ & $21.8 \pm 0.25$ \\
\hline $2: 00$ & $21.2 \pm 0.07$ & $21.1 \pm 0.14$ & $21.6 \pm 0.29$ & $20.9 \pm 0.12$ \\
\hline $3: 00$ & $20.7 \pm 0.25$ & $21.3 \pm 0.24$ & $20.9 \pm 0.51$ & $20.8 \pm 0.24$ \\
\hline $4: 00$ & $20.0 \pm 0.40$ & $20.2 \pm 0.54$ & $19.8 \pm 0.79$ & $20.0 \pm 0.41$ \\
\hline $5: 00$ & $19.6 \pm 0.23$ & $20.3 \pm 0.58(2)$ & $19.0 \pm 0.54(1,3)$ & $19.8 \pm 0.38(2)$ \\
\hline $6: 00$ & $20.2 \pm 0.17$ & $20.0 \pm 0.40(3)$ & $19.3 \pm 0.23 *(3)$ & $20.4 \pm 0.24(1,2)$ \\
\hline $7: 00$ & $22.1 \pm 0.25$ & $25.7 \pm 0.44 *(3)$ & $22.0 \pm 0.50(3)$ & $22.7 \pm 0.44(1,2)$ \\
\hline $8: 00$ & $24.0 \pm 0.40$ & $26.6 \pm 0.22 *(2)$ & $24.8 \pm 0.36(1,3)$ & $25.6 \pm 0.38 *(2)$ \\
\hline 9:00 & $26.6 \pm 0.39$ & $28.8 \pm 0.37 *$ & $28.1 \pm 0.42 *$ & $27.8 \pm 0.31$ \\
\hline $10: 00$ & $29.6 \pm 0.43$ & $32.0 \pm 0.46^{*}$ & $31.9 \pm 0.65^{*}$ & $31.0 \pm 0.38^{*}$ \\
\hline $11: 00$ & $31.9 \pm 0.38$ & $34.2 \pm 0.31 *(2,3)$ & $32.7 \pm 0.25(1)$ & $33.0 \pm 0.31 *(1)$ \\
\hline $12: 00$ & $35.0 \pm 0.54$ & $34.9 \pm 0.27(2)$ & $34.0 \pm 0.14(1,3)$ & $34.5 \pm 0.21(2)$ \\
\hline $13: 00$ & $35.0 \pm 0.54$ & $35.0 \pm 0.13 *(2)$ & $34.2 \pm 0.09 *(1,3)$ & $34.5 \pm 0.21 *(2)$ \\
\hline $14: 00$ & $36.2 \pm 0.16$ & $34.3 \pm 0.05 *(2,3)$ & $34.0 \pm 0.09 *(1,3)$ & $34.6 \pm 0.15 *(1,2)$ \\
\hline $15: 00$ & $35.9 \pm 1.41$ & $34.7 \pm 0.23$ & $34.8 \pm 0.28$ & $35.2 \pm 0.21$ \\
\hline $16: 00$ & $34.7 \pm 0.19$ & $34.0 \pm 0.21$ & $34.2 \pm 0.35$ & $34.2 \pm 0.35$ \\
\hline $17: 00$ & $34.3 \pm 0.28$ & $33.8 \pm 0.21$ & $34.3 \pm 0.21$ & $34.0 \pm 0.28$ \\
\hline $18: 00$ & $33.4 \pm 0.31$ & $32.5 \pm 0.40$ & $34.2 \pm 0.65$ & $33.7 \pm 0.43$ \\
\hline $19: 00$ & $32.4 \pm 0.52$ & $30.0 \pm 0.34$ & $30.2 \pm 0.47^{*}$ & $29.6 \pm 0.33^{*}$ \\
\hline $20: 00$ & $29.1 \pm 0.29$ & $27.3 \pm 0.55^{*}$ & $27.5 \pm 0.25 *$ & $27.1 \pm 0.24 *$ \\
\hline $21: 00$ & $27.2 \pm 0.28$ & $25.9 \pm 0.47^{*}$ & $25.3 \pm 0.49 *$ & $25.4 \pm 0.35^{*}$ \\
\hline $22: 00$ & $25.9 \pm 0.37$ & $23.9 \pm 0.32 *$ & $24.6 \pm 0.12 *$ & $24.7 \pm 0.12 *$ \\
\hline $23: 00$ & $25.8 \pm 0.73$ & $23.7 \pm 0.12$ & $23.8 \pm 0.12$ & $22.8 \pm 0.41$ \\
\hline $24: 00$ & $23.3 \pm 0.30$ & $23.3 \pm 0.17$ & $23.6 \pm 0.25$ & $23.5 \pm 0.49$ \\
\hline
\end{tabular}

Note: see Table 1.

in the cattle barn, it remained on average $7.9-11.7 \%$ higher than outside. In the evening, even before sunset, the difference was significant (6.1-12.4\%), and only after dark and at midnight did it make only 3.4-4.1\%. Throughout the day, the relative humidity in the cattle barn was higher than outside, due to the release of moisture by the animals and evaporation from the surface of the frame structures. 
In different parts of the uninsulated barn, the relative humidity was also different (Table 5). From 9:00 am to 6:00 pm it was $0.5-7.2 \%$ higher in the central part of the premise than in its front parts. In the morning and evening hours, as well as at night in the southeastern part of the premise, the relative humidity was higher (by $0.5-6.2 \%$ ). In the northwestern part of the barn, this figure was lower throughout the day.

Table 5

\section{Dynamics of the air relative humidity in an uninsulated cow barn during 24 hours $(n=134, \bar{X} \pm S E)$}

\begin{tabular}{|c|c|c|c|c|}
\hline & Outside & \multicolumn{3}{|c|}{ Premise } \\
\hline Day time & in shade & southeast side1 & cetral part2 & northwest side3 \\
\hline $1: 00$ & $49.3 \pm 0.29$ & $49.5 \pm 0.75(2,3)$ & $50.8 \pm 0.73^{*}(1)$ & $52.3 \pm 0.29 *(1)$ \\
\hline $2: 00$ & $49.3 \pm 0.55$ & $51.0 \pm 0.47(3)$ & $51.5 \pm 0.75(3)$ & $55.0 \pm 0.47 *(1,2)$ \\
\hline $3: 00$ & $49.5 \pm 0.49$ & $51.5 \pm 0.45^{*}(2,3)$ & $51.9 \pm 0.43^{*}(1,3)$ & $55.3 \pm 0.39 *(1,3)$ \\
\hline $4: 00$ & $52.5 \pm 1.20$ & $52.5 \pm 0.61(3)$ & $55.0 \pm 1.14(3)$ & $57.1 \pm 0.74 *(1,2)$ \\
\hline $5: 00$ & $54.1 \pm 0.64$ & $52.7 \pm 0.65(2,3)$ & $56.1 \pm 0.96(1)$ & $57.4 \pm 0.74 *(1)$ \\
\hline $6: 00$ & $53.5 \pm 0.79$ & $53.5 \pm 0.37(2,3)$ & $56.5 \pm 0.24^{*}(1,3)$ & $57.8 \pm 0.44^{*}(1,2)$ \\
\hline $7: 00$ & $51.0 \pm 0.35$ & $50.2 \pm 1.98$ & $55.0 \pm 0.71 *$ & $55.6 \pm 0.45^{*}$ \\
\hline $8: 00$ & $48.8 \pm 0.77$ & $46.8 \pm 0.66(2,3)$ & $51.3 \pm 0.67 *(1)$ & $52.8 \pm 1.00^{*}(1)$ \\
\hline $9: 00$ & $47.5 \pm 0.62$ & $45.0 \pm 0.49 *(2,3)$ & $50.2 \pm 0.34 *(1)$ & $49.5 \pm 0.37 *(1)$ \\
\hline $10: 00$ & $40.4 \pm 1.71$ & $40.8 \pm 0.83(2)$ & $44.3 \pm 1.21(1,3)$ & $42.6 \pm 1.67(2)$ \\
\hline $11: 00$ & $34.0 \pm 1.75$ & $35.9 \pm 1.47(2)$ & $40.4 \pm 0.97 *(1,3)$ & $37.6 \pm 1.57(2)$ \\
\hline $12: 00$ & $26.1 \pm 1.75$ & $30.9 \pm 1.10(2,3)$ & $38.1 \pm 0.48^{*}(1,3)$ & $32.9 \pm 1.48^{*}(1,2)$ \\
\hline $13: 00$ & $16.6 \pm 1.35$ & $25.9 \pm 1.26 *(2,3)$ & $29.9 \pm 1.61 *(1)$ & $29.1 \pm 0.98^{*}(1)$ \\
\hline $14: 00$ & $15.3 \pm 0.23$ & $22.7 \pm 0.37 *(2,3)$ & $27.3 \pm 0.37 *(1)$ & $26.8 \pm 0.52^{*}(1)$ \\
\hline $15: 00$ & $14.0 \pm 1.41$ & $22.5 \pm 0.71$ & $28.0 \pm 1.41$ & $25.5 \pm 0.71$ \\
\hline $16: 00$ & $13.5 \pm 2.12$ & $23.0 \pm 0.51$ & $27.0 \pm 1.41$ & $24.5 \pm 0.71$ \\
\hline $17: 00$ & $15.0 \pm 0.51$ & $23.0 \pm 0.49$ & $28.5 \pm 0.71$ & $25.5 \pm 0.71$ \\
\hline $18: 00$ & $20.5 \pm 2.13$ & $25.2 \pm 0.52(2)$ & $28.8 \pm 1.18^{*}(1,3)$ & $25.7 \pm 1.93(2)$ \\
\hline $19: 00$ & $21.8 \pm 0.78$ & $30.1 \pm 0.65^{*}(2,3)$ & $36.1 \pm 0.82(1,3)$ & $36.3 \pm 0.83^{*}(1,2)$ \\
\hline $20: 00$ & $27.0 \pm 1.25$ & $36.0 \pm 1.15^{*}(3)$ & $38.3 \pm 0.56^{*}(3)$ & $39.9 \pm 0.50^{*}(1,2)$ \\
\hline $21: 00$ & $37.5 \pm 0.33$ & $39.8 \pm 0.29 *(3)$ & $40.3 \pm 2.42(3)$ & $44.3 \pm 0.29 *(1,2)$ \\
\hline $22: 00$ & $39.4 \pm 1.52$ & $41.0 \pm 1.54$ & $44.6 \pm 0.97 *$ & $45.0 \pm 0.61 *$ \\
\hline $23: 00$ & $44.0 \pm 0.71$ & $46.0 \pm 1.22$ & $48.0 \pm 0.51$ & $48.3 \pm 0.41$ \\
\hline $24: 00$ & $45.0 \pm 0.94$ & $47.3 \pm 0.99(3)$ & $49.5 \pm 0.33^{*}(3)$ & $50.5 \pm 0.75^{*}(1,2)$ \\
\hline
\end{tabular}

Note: see Table 1. 
The obtained data indicate that the temperature-humidity regime in the uninsulated barn was changing significantly during the day (Figure 6). The correlation coefficient between the temperature and the relative humidity of the premise was high $\mathrm{r}=-0,884(\mathrm{P}<0,05)$.

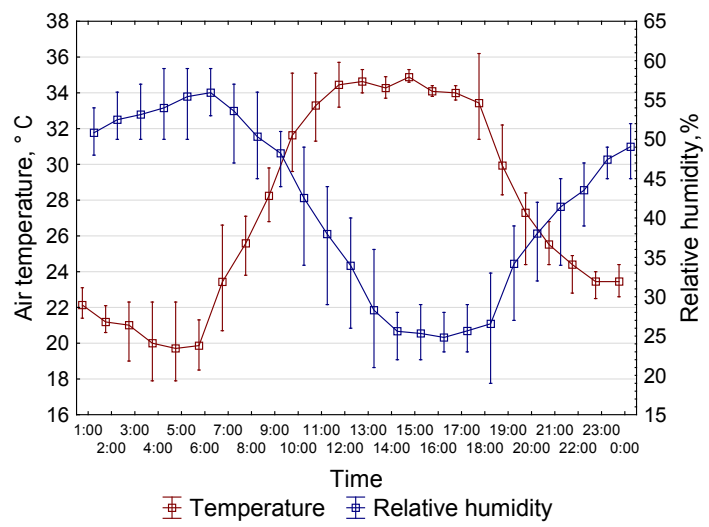

Figure 6. Temperature and humidity regime inside the uninsulated barn (temperature - dark-red line; relative humidity - blue line), $\mathrm{n}=\mathbf{4 0 2}$

The construction of a linear regression model (Figure 7) shows the high relative conditionality of the premise temperature and relative humidity

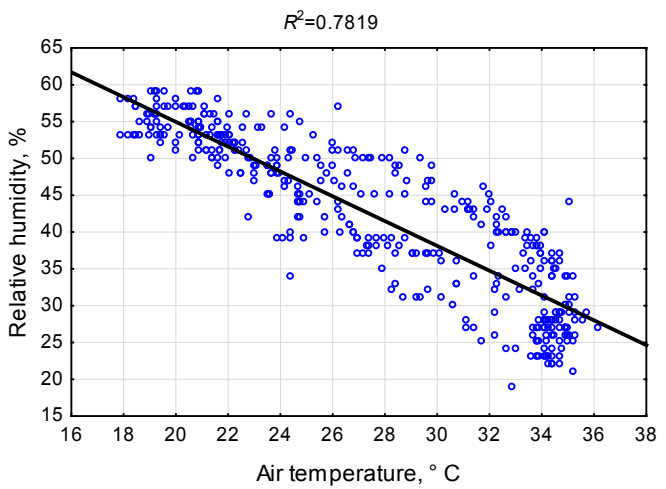

Figure 7. Relationship between air temperature and relative humidity in an uninsulated barn, $n=402$ 
$\left(R^{2}=0.78\right)$. As the temperature in the cattle barn rises by $1{ }^{\circ} \mathrm{C}$, the relative humidity will decrease by about $1.7 \%$.

Under such conditions, to characterize the state of the indoor air environment, as well as to evaluate the individual effect of temperature and relative humidity on animals is quite difficult without the use of an integral indicator that would take into account their joint effect on the body of dairy cows. The temperaturehumidity index (THI) has long been used to assess the comfort of cattle in heat conditions and is perfectly acceptable under these circumstances.

During the study, the THI in the external environment was found to range from 64.9 to 79.7 units. In the uninsulated barn, the THI varied from 64.1 to 81.0 units. The difference between the average THI outside and inside the uninsulated barn, depending on the part of the building (Table 6), was 0.1-2.7 units.

However, in different parts of the premise (Figure 7), depending on the time of day, the largest difference in the value of THI was 2.5-4.4 units, exceeding the comfortable value for dairy cows (THI <68), even in the morning and evening hours.

We associate the observed differences in the temperature-humidity index in different parts of the premise with its design features and the location relative to the sides of the world, i.e. with different level of their heating by rays of sunlight, which should include a selective approach to the application of additional cooling (for example, irrigation ) based on the differences found.

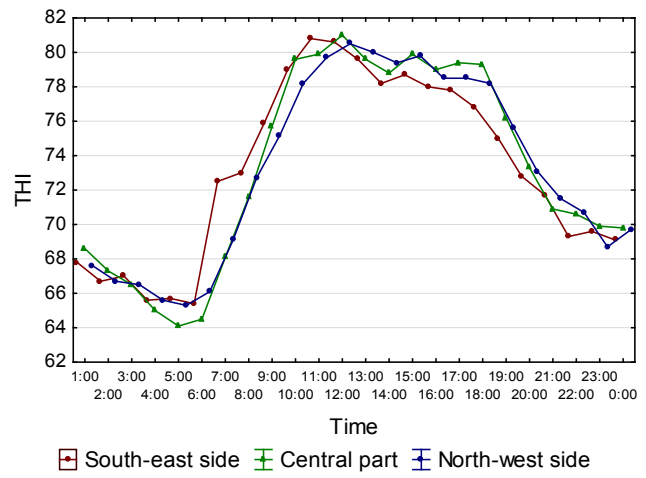

Figure 8. Dynamics of temperature-humidity index in the uninsulated barn (southeast side - dark-red line; central part - green line; northwest side - blue line), $n=134$ 
Table 6 Dynamics of the temperature-humidity index value in an uninsulated cow barn during 24 hours $(\mathrm{n}=134, \bar{X} \pm S E)$

\begin{tabular}{|c|c|c|c|c|}
\hline & Outside & \multicolumn{3}{|c|}{ Premise } \\
\hline Day time & in shade & southeast side1 & cetral part2 & northwest side3 \\
\hline $1: 00$ & $68.1 \pm 0.26$ & $67.8 \pm 0.41$ & $68.6 \pm 0.23$ & $67.6 \pm 0.31$ \\
\hline $2: 00$ & $66.6 \pm 0.10$ & $66.7 \pm 0.16$ & $67.3 \pm 0.36$ & $66.7 \pm 0.19$ \\
\hline $3: 00$ & $66.1 \pm 0.31$ & $67.0 \pm 0.31$ & $66.5 \pm 0.67$ & $66.5 \pm 0.33$ \\
\hline $4: 00$ & $65.3 \pm 0.61$ & $65.6 \pm 0.71$ & $65.0 \pm 1.05$ & $65.6 \pm 0.60$ \\
\hline $5: 00$ & $64.9 \pm 0.28$ & $65.7 \pm 0.73$ & $64.1 \pm 0.67$ & $65.3 \pm 0.47$ \\
\hline $6: 00$ & $65.7 \pm 0.21$ & $65.4 \pm 0.52(2)$ & $64.5 \pm 0.32 *(1,3)$ & $66.1 \pm 0.33(2)$ \\
\hline $7: 00$ & $67.9 \pm 0.32$ & $72.5 \pm 0.65 *(2,3)$ & $68.1 \pm 0.63(1)$ & $69.1 \pm 0.59(1)$ \\
\hline $8: 00$ & $70.3 \pm 0.45$ & $73.0 \pm 0.21 *(2)$ & $71.6 \pm 0.47(1,3)$ & $72.7 \pm 0.41 *(2)$ \\
\hline 9:00 & $73.5 \pm 0.47$ & $75.9 \pm 0.44 *$ & $75.7 \pm 0.54 *$ & $75.2 \pm 0.37 *$ \\
\hline $10: 00$ & $76.2 \pm 0.26$ & $79.0 \pm 0.43 *(3)$ & $79.6 \pm 0.71 *(3)$ & $78.2 \pm 0.24 *(1,2)$ \\
\hline $11: 00$ & $77.8 \pm 0.24$ & $80.8 \pm 0.25 *(2,3)$ & $79.9 \pm 0.19 *(1)$ & $79.7 \pm 0.19 *(1)$ \\
\hline $12: 00$ & $79.7 \pm 0.28$ & $80.6 \pm 0.32(3)$ & $81.0 \pm 0.12 *(3)$ & $80.5 \pm 0.12(1,2)$ \\
\hline 13:00 & $78.9 \pm 0.17$ & $79.6 \pm 0.31(3)$ & $79.6 \pm 0.35(3)$ & $80.0 \pm 0.17 *(1,2)$ \\
\hline $14: 00$ & $78.6 \pm 0.17$ & $78.2 \pm 0.03(2,3)$ & $78.8 \pm 0.16(1)$ & $79.4 \pm 0.21 *(1)$ \\
\hline $15: 00$ & $78.1 \pm 1.63$ & $78.7 \pm 0.21$ & $79.9 \pm 0.05$ & $79.8 \pm 0.35$ \\
\hline $16: 00$ & $76.8 \pm 0.42$ & $78.0 \pm 0.21$ & $79.0 \pm 0.07$ & $78.5 \pm 0.21$ \\
\hline $17: 00$ & $76.8 \pm 0.21$ & $77.8 \pm 0.21$ & $79.4 \pm 0.07$ & $78.5 \pm 0.42$ \\
\hline $18: 00$ & $76.9 \pm 0.51$ & $76.8 \pm 0.37(2,3)$ & $79.3 \pm 0.51 *(1)$ & $78.2 \pm 0.57(1)$ \\
\hline $19: 00$ & $76.2 \pm 0.45$ & $75.0 \pm 0.30(2)$ & $76.2 \pm 0.42 *(1,3)$ & $75.6 \pm 0.26(2)$ \\
\hline 20:00 & $73.5 \pm 0.16$ & $72.8 \pm 0.53$ & $73.3 \pm 0.25$ & $73.1 \pm 0.23$ \\
\hline 21:00 & $72.9 \pm 0.34$ & $71.7 \pm 0.57$ & $70.9 \pm 0.79$ & $71.5 \pm 0.42$ \\
\hline $22: 00$ & $71.6 \pm 0.42$ & $69.3 \pm 0.40 *(2,3)$ & $70.6 \pm 0.09(1)$ & $70.7 \pm 0.10(1)$ \\
\hline 23:00 & $72.0 \pm 0.92$ & $69.6 \pm 0.24$ & $69.9 \pm 0.16$ & $68.7 \pm 0.57$ \\
\hline $24: 00$ & $69.0 \pm 0.30$ & $69.1 \pm 0.21$ & $69.8 \pm 0.32$ & $69.7 \pm 0.62$ \\
\hline
\end{tabular}

Note: see Table 1.

It is known from literature [8, p. 56; 10, p. 47; 14, p. 14; 15, p. 379], an increase in THI up to 72 units causes a decrease in milk yield in dairy cows, with THI thresholds being even lower for milk fat and protein content. Consequently, the found differences of 2-4 units of THI in different sections of the barn can affect the milk yield and composition of individual animals. 
It should be noted that this study in an uninsulated premise was conducted in the conditions of round-the-clock operation of axial fans of large diameter. However, the air velocity at the rest place of the animals was small (up to $0.9 \mathrm{~m} / \mathrm{s}$ ), and only near the feed table did its maximum mobility reach $2.8-3.6 \mathrm{~m} / \mathrm{s}$. However, no significant difference in air velocity in the ends of the barn and its central part was found.

\section{Conclusions}

Simultaneous continuous 24-hour recording of temperature and relative humidity in uninsulated cattle barns built according to the resource-saving technology and in the external environment during the hot summer allowed us to find out some peculiarities in the formation of their microclimate. The use of a temperature-humidity index (THI) for both the characterization of the state of the air environment and its effects on the animal body was convenient and informative. Not only differences between the state of the ambient air inside and outside the premises were revealed, but also a significant difference in its formation in different parts of the premises. They were related to the location of the cattle barn relative to the sides of the world - that is, the intensity of the warming of individual parts of the premises by the sun during the light period of the day. Despite the high dependence of the climate in the cattle barns on the state of the environment, their design features prevent excessive air overheating during the heat of the day on the one hand (creating shady protection for animals), and on the other - lead to capture of the heated indoor air when it cools in the environment thus prolonging the effects of elevated temperatures on the body. The revealed peculiarities regarding the formation of the air environment indicate the need for a differentiated approach to the mode and duration of the application of cooling systems during the day for different parts of the premise with natural ventilation. The results of our studies showed that even round-the-clock use of powerful axial fans was insufficient to create satisfactory microclimate conditions at the animal resting place, as the temperature-humidity index exceeded cow-friendly values (THI $>68$ ) for 18 hours per day. This points to the need for additional technical solutions (for example, irrigation) to normalize the microclimate in cattle barns in hot summer. 


\section{References:}

1. Voloshchuk, V. M., \& Khotsenko, A. V. (2017). Dynamika temperatury povitria ta vnutrishnikh elementiv konstruktsii korivnyka karkasnoho typu za dii faktoriv zovnishnoho seredovyshcha [Dynamics of air temperature and internal structural elements of the barn frame type on effects of environmental factors]. Visnyk Sumskoho natsionalnoho ahrarnoho universytetu. Seriia: Tvarynnytstvo, 5(2), 37-41. (in Ukrainian)

2. Vtoryi, V.F., Vtoryi, S.V., Ilin, R.M. (2018). Model temperaturnovlajnostnogo rejima korovnika $\mathrm{v}$ zavisimosti ot parametrov vneshney sredyi [Model of in-barn temperature and humidity depending on outside environment parameters]. Tehnologii i tehnicheskie sredstva mehanizirovannogo proizvodstva produktsii rastenievodstva i jivotnovodstva, 96, 203-209. (in Russian)

3. Ilin, R.M., Vtoryiy, S.V. (2017). Obosnovanie parametrov sistemyi monitoringa mikroklimata $\mathrm{v}$ jivotnovodcheskih pomescheniyah [Substantiation of parameters of climate monitoring system in livestock houses]. Tehnologii i tehnicheskie sredstva mehanizirovannogo proizvodstva produktsii rastenievodstva i jivotnovodstva, 92, 212-217. (in Russian)

4. Loshkarev, I.Yu., Aberyasev, A.Ya., Loshkarev, V.I. (2018). Otsenka effektivnosti vnedreniya svetoaeratora v sistemu ventilyatsii korovnika [Evaluation of the effectiveness of introducing a light aerator into the barn ventilation system]. Aktualnyie problemyi energetiki APK, 104-105. (in Russian)

5. Antonenko, P.P.; Dorovskych, A.V.; Vysokos, M.P.; Mylostyvyi, R.V.; Kalinichenko, O.O.; Vasilenko, T.O. Methodological Bases and Methods of Scientific Research in Veterinary Hygiene, Sanitary and Expertise; Svidler, A.L.: Dnipro, Ukraine, 2018; p. 276.

6. Trofimov, A.F., Timoshenko, V.N., Muzyika, A.A., Moskalev, A.A., Kovalevskiy, I.A., SHeygratsova, L.N. (2014). Formirovanie mikroklimata v jivotnovodcheskih pomescheniyah razlichnogo tipa dlya soderjaniya laktiruyuschih korov [The formation of a microclimate in livestock buildings of various types for the maintenance of lactating cows]. Uchenyie zapiski uchrejdeniya obrazovaniya Vitebskaya ordena Znak pocheta gosudarstvennaya akademiya veterinarnoy meditsinyi, 50(2-1), 331-335. (in Russian)

7. Fedorenko, I.Ya., Kapustin, N.I., Kapustin, V.N., Byirdin, I.N. (2010). Matematicheskoe modelirovanie svobodnoy (estestvennoy) konvektsii $\mathrm{V}$ jivotnovodcheskih pomescheniyah bolshoy vmestimosti [Mathematical modeling of free (natural) convection in large-capacity livestock buildings]. Vestnik Altayskogo gosudarstvennogo agrarnogo universiteta, 11(73), 66-70. (in Russian)

8. Gantner, V., Mijić, P., Kuterovac, K., Solić, D., \& Gantner, R. (2011). Temperature-humidity index values and their significance on the daily production of dairy cattle. Daily production of dairy cattle, Mljekarstvo, 61(1), 56-63.

9. Jovović, V., Pandurević, T., Važić, B., \& Erbez, M. (2019). Microclimate parameters and ventilation inside the barns in the lowland region of Bosnia and Herzegovina. Journal of Animal Science of bih, 1(2). doi:10.7251/jas1502014j

10. Mylostyvyi, R. V., \& Sejian, V. (2019). Welfare of dairy cattle in conditions of global climate change. Theoretical and Applied Veterinary Medicine, 7(1), 47-55. doi:10.32819/2019.71009 
11. Mylostyvyi, R., \& Chernenko, O. (2019). Correlations between environmental factors and milk production of Holstein cows. Data, 4(3), 103. doi:10.3390/data4030103

12. Mylostyvyi, R., Chernenko, O., \& Lisna, A. (2019). Prediction of comfort for dairy cows, depending on the state of the environment and the type of barn. Development of Modern Science: The Experience of European Countries and Prospects for Ukraine. doi:10.30525/978-9934-571-78-7_53

13. Mylostyvyi, R.V., Chernenko, O.M., Izhboldina, O.O., Puhach, A.M., Orishchuk, O.S., Khmeleva, O.V. (2019). Ecological substantiation of the normalization of the state of the air environment in the uninsulated barn in the hot period. Ukrainian Journal of Ecology, 9(3), 84-91.

14. Samal, L. (2013). Heat Stress in Dairy Cows - Reproductive Problems and Control Measures. International Journal of Livestock Research, 3(3), 14-23.

15. Tamami, F. Z., Hafezian, H., Mianji, G.R., Abdullahpour, R., \& Gholizadeh, M. (2018). Effect of the temperature-humidity index and lactation stage on milk production traits and somatic cell score of dairy cows in Iran. Songklanakarin J. Sci. Technol. 40(2), 379-383.

16. Teye, F., Hautala, M., Pastell, M., Praks, J., Veermae, I., Poikalainen, V., Pajumagi, A., Kivinen, T., Ahokas, J. (2007). Microclimate in cattle barns in Finland and Estonia. ISAH-2007 Tartu, Estonia. https://www.isah-soc.org/userfiles/ downloads/proceedings/Proc_ISAH_2007_Volume_I/14_Teye.pdf

17. Wang, X., Zhang, G., \& Chöi, C. Ȳ. (2018). Evaluation of a precision airsupply system in naturally ventilated freestall dairy barns. Biosystems Engineering, 175, 1-15. doi:10.1016/j.biosystemseng.2018.08.005 